\title{
New wild Brassica oleracea L. germplasm at its western distribution limit in the Iberian Peninsula
}

\author{
Jaime Fagúndez ${ }^{1}$, María Elena Cartea ${ }^{2}$ \& Margarita Lema ${ }^{3}$
}

\begin{abstract}
Fagúndez, J., Cartea, M.E. \& Lema, M. New wild Brassica oleracea L. germplasm at its western distribution limit in the Iberian Peninsula. Lazaroa 36: 51-57 (2015).

An exploration and collection mission for wild Brassica oleracea populations was carried out in spring and summer of 2013. The aim of this collection was to expand the number of accessions of wild Brassica oleracea available for basic and applied research in plant breeding. In this paper we report a new population of wild Brassica oleracea in an unexplored coastal area of Galicia, NW Iberian Peninsula. Details of population ecology and vegetation, soil, climate and geographic data were recorded for this population. The "Endangered" threat category for the region is proposed, and actions for in situ and ex situ conservation are proposed. Seeds will be added to the germplasm collections of University of Santiago de Compostela and Misión Biológica de Galicia (CSIC) for further research on diverse aspects of the dynamics and ecophysiology of the population along with characterization and evaluation of useful traits.
\end{abstract}

Keywords: Germplasm collection, wild relatives, plant conservation, Brassicaceae, Galicia.

Resumen: Fagúndez, J., Cartea, M.E. \& Lema, M. Nuevos datos sobre poblaciones silvestres de Brassica oleracea en su límite de distribución occidental en la Península Ibérica. Lazaroa 36: $51-57$ (2015).

En la primavera y el verano de 2013 se llevó a cabo un estudio que incluía la exploración y recolección de poblaciones silvestres de Brassica oleracea. El objetivo de esta colección era ampliar el número de muestras de germoplasma de esta especie disponibles para la investigación básica y aplicada al fitomejoramiento. En este trabajo se presentan nuevos datos sobre poblaciones de Brassica oleracea silvestre en un área costera inexplorada de Galicia, en el noroeste de la Península Ibérica. Detalles de la ecología de la población y la vegetación, el suelo, el clima y los datos geográficos se registraron para esta población. Se propone la categoría de amenaza para la región, y las acciones para su correcta conservación in situ y ex situ. Las muestras de semillas se añadirán a las colecciones de germoplasma de la Universidad de Santiago de Compostela y de la Misión Biológica de Galicia (CSIC) para futuras investigaciones sobre diversos aspectos de la dinámica y la ecofisiología de la población junto con la caracterización y evaluación de características útiles.

Palabras clave: Colección de germoplasma, plantas silvestres, conservación vegetal, Brassicaceae, Galicia.

\section{INTRODUCTION}

Brassica oleracea L. (Brassicaceae) is a perennial species that occurs in maritime cliffs of the Atlantic coasts, from the Isle of Helgoland in Germany to the Cantabrian Sea in Northern Spain (Mitchell \& Richards, 1978; SNOGERUP \& al., 1990; GómEZ-CAMPO \& al., 2005). Some authors have suggested an anthropogenic origin for the wild populations, escaped and naturalized from nearby cultivated plants (MitchELL, 1976; MitChell \& RichaRdS, 1979 for UK populations). In northern Spain, its native status is widely accepted, based mainly on its distinct ecology (FERnANDEZ-Prieto \& HERreraGallastegui, 1992; Gómez-Campo \& al., 2005). The known distribution of the wild native populations in Spain covers the Cantabrian

\footnotetext{
${ }^{1}$ Department of Plant and Animal Biology and Ecology, University of A Coruña, Faculty of Science, E-15071 A Coruña, Spain. E-mail: jaime.fagundez@udc.es

${ }^{2}$ Misión Biológica de Galicia, Spanish National Research Council, P.O. Box 28, E-36080 Pontevedra, Spain. E-mail: ecartea@mbg.csic.es

${ }^{3}$ Department of Cellular Biology and Ecology, University of Santiago de Compostela, Avd. Lope Gómez de Marzoa s/n, E15782, Santiago de Compostela, Spain. E-mail: margarita.lema@usc.es
} 
coasts, from near San Sebastián in the Basque Country to Cape Vidio in Asturias (GómezCAMPO \& al., 2005). In Galicia, there are no references of wild populations of $B$. oleracea except as occasionally escaped from cultivated fields (MERINo, 1905; Rigueiro RodrígueZ, 1977). However, just as for other Brassica species (B. napus, B. rapa), it represents a significant element of the traditional agrosystems and human diet in Galicia (ORDÁs \& CARTEA, 2008).

The relevance of the wild populations of $B$. oleracea has been highlighted because they may constitute a reservoir of genetic variation, and be a source of resistance to different biotic (diseases and pest) and abiotic (salinity, drought) stresses affecting improved cultivars of the species, by means of crossing and genetic improvement (NeWTON \& al., 2010). Moreover, they are needed to understand the phylogeography of the species and related taxa, its center of origin and historical dispersal throughout the region (GUSTAFSSON \& LANNER-HERRERA, 1997; MEI \& al., 2010). The collection, conservation and careful utilization of plant genetic resources, including wild populations, will also be crucial for sustainable crop production and improvement.

As part of an on-going study on wild relatives of the Brassiceae tribe in Galicia, we performed an intense survey along the coast of northern Galicia to determine the presence or absence of wild populations of the species in the area. In this communication we present the results of our survey with comments on the ecology, native status, and conservation of $B$. oleracea in the region.

\section{MATERIALS AND METHODS}

\section{THE SPECIES}

Brassica oleracea (Brassicaceae) is a perennial plant up to 2 meters high, with broad, glaucus leaves of up to $40 \mathrm{~cm}$ in rosette at the apex of a thick rounded stem. The bright yellow flowers of up to $4 \mathrm{~cm}$ are borne in long racemes. The fruit is a silique of up to $10 \mathrm{~cm}$, with many seeds. Chromosome number is $2 \mathrm{n}=18$ (Gómez-
CAMPO, 1995). It belongs to Brassica sect. Brassica, a highly diverse section with several endemic species throughout the Mediterranean area (BRANCA \& CARTEA, 2011). The most economically important crops of $B$. oleracea are cabbage (capitata group), cauliflower (botrytis botrytis group), broccoli (botrytis italica group), Brussels sprouts (gemmifera group) and kale (acephala group) (CARTEA \& al., 2011).

\section{Study AREA, Field SURVEY AND COLlection}

Galicia is located at the northwest corner of the Iberian Peninsula, with a large coastline of c. $1500 \mathrm{~km}$. Its coastal area is included in the Atlantic biogeographic region (RIVAS-MARTíNEZ $\&$ al., 2002). The coast of Lugo is considered part of the Galician-Asturian sector, shared with the Cantabrian coasts where B. oleracea is known. The rest of the Galician coast belongs to the Galician-Portuguese sector, with a higher influence of Mediterranean climate and floristic elements.

During May and June 2013 we visited several localities covering a total of c. $140 \mathrm{~km}$, along the target area (Figure 1). Previously, the westernmost previously known population at Cudillero (Asturias, figure 1, GómEZ CAMPO \& al., 2005) was visited as training for visual identification. In addition, 13 localities were visited in other coastal areas of Galicia (Figure 1) exploring all the three Galician coastal provinces. Cliffs were prospected with binoculars, covering an area of $\mathrm{c}$. $1 \mathrm{~km}$ at each site. Whenever B. oleracea was present, we prospected that particular site to establish the population extent. We estimated the population size by counting individuals in several points. Plant material was collected and herbarium sheets were prepared and included at SANT herbarium (http://www.usc.es/herbario). Ecology, phenology, vegetation type and geology data were also collected. In July 2013 we collected seeds from 60 plants covering the total area whenever plants could be reached with a pruning shear on a 4-metre extension (Figure 2F). Seeds were dried and stored at the SANT-BG germplasm collection at the University of Santiago de 


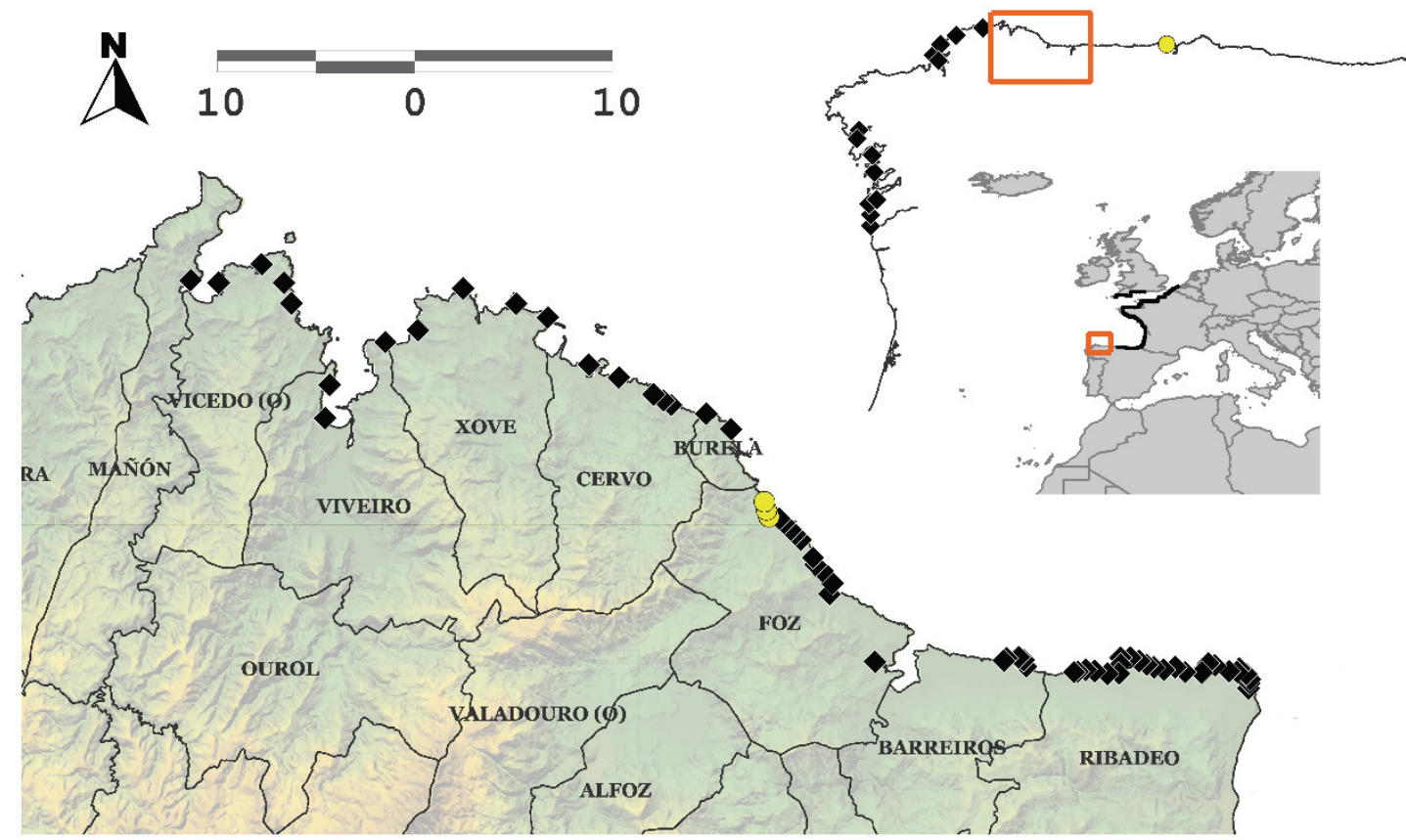

Figure 1.- Location of the survey area in Europe and Northwestern Spain, showing the closest population of $B$. oleracea in Cudillero, Asturias (circles) and all prospected localities along the coast of Galicia (diamonds, upright map). Prospected area of a wild population found in Foz (yellow circles) and all localities studied (diamonds, down-left map). The black line along Western Europe coast represents the approximate distribution of the wild populations of $B$. oleracea.

Compostela and at the Misión Biológica de Galicia Germplasm Bank (Spanish National Research Council) under cold and dry conditions following the usual procedures (FAGÚNDEZ \& al., 2010).

\section{RESULTS}

No populations were found in the regional general survey (Figure 1). In the target area, a total of 63 localities were visited covering an area of $\mathrm{c}$. $140 \mathrm{~km}$. One single population of B. oleracea was found at Cangas de Foz (Foz council, Lugo province, centre at $42.62^{\circ} \mathrm{N} ; 7.33^{\circ} \mathrm{W}$, Figures 1,2 ).

The population covers a $1.8 \mathrm{~km}$ coastline with an altitudinal range of 0-30 meters above sea level. We estimated a total of 400 reproductive plants. About 30 seedlings were observed in a reduced area associate to a natural spring and immature plants were frequent (c. $40 \%$ of total population). Flowering at the end of May was about $70 \%$, with some plants bearing undeveloped siliques. Remarkably, several plants had white and yellow discolored flowers. Black rot symptoms, caused by Xanthomonas campestris pv. campestris, were detected in several plants. Unidentified aphids were also observed in some individuals of the population.

According to Papadakis classification (1966), the area belongs to the climate type maritime-temperate, with an average annual rainfall (20 years) of $1026 \mathrm{~mm}$ and an average temperature of $13.9^{\circ} \mathrm{C}$ (CARBAlleira \& al., 1983). Orientation is mainly $\mathrm{N}, \mathrm{NE}$ and NW but in-and-outs on the shoreline with any orientation are found. Schist is the bed rock. Sedimentary sandy soils with alluvial materials develop in top layers, which can be classified as Haplic Umbrisol according to FAO, ISRIC, and ISSS (1998) (Figure 2E). It has a sandy loam texture and a granular structure, with an udic moisture regime and a mesic soil temperature regime according to FAO (2006). 

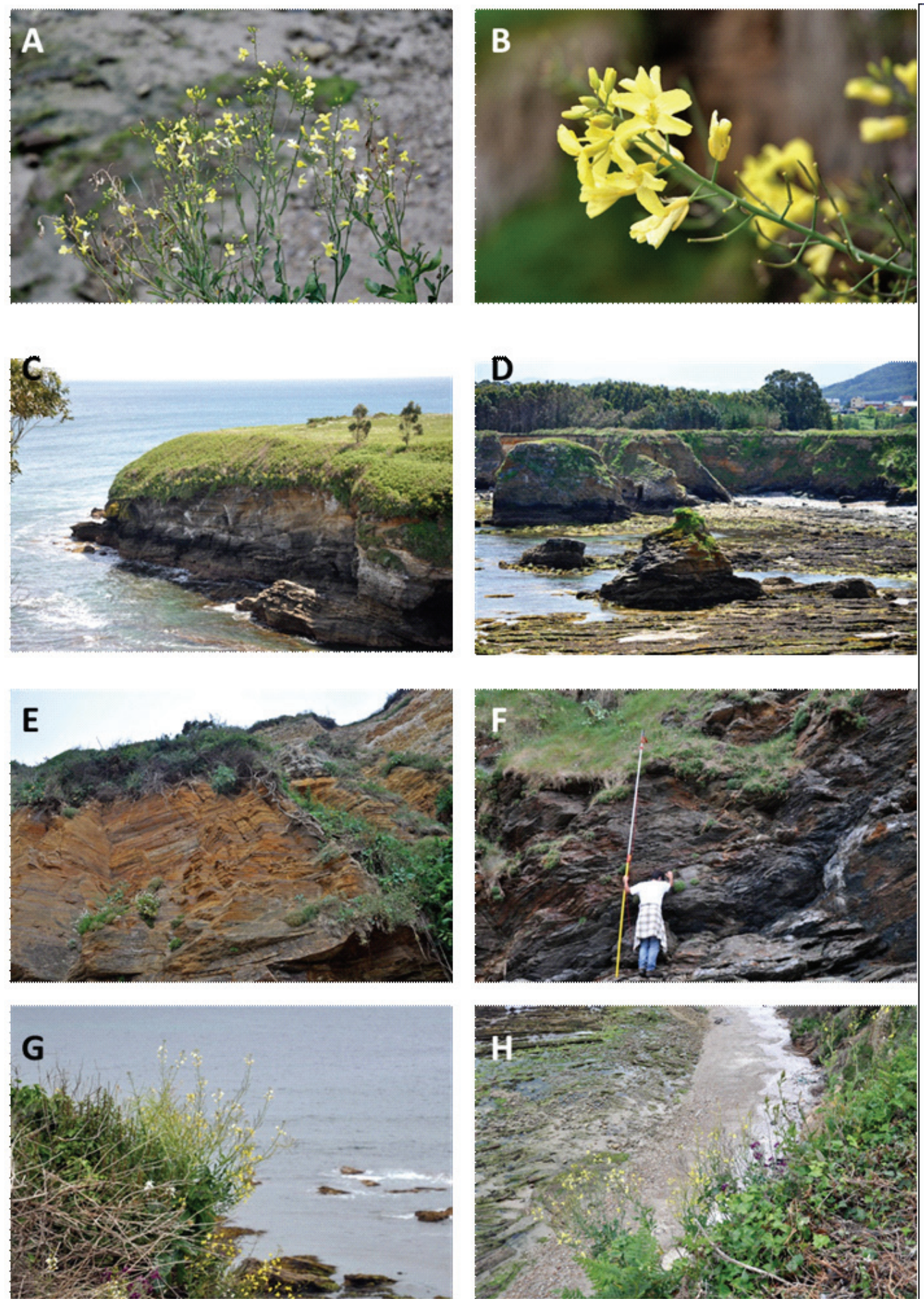

Figure 2. - A, B: Detail of flowers and inflorescence of Brassica oleracea; C, D: General view of the new discovered population; E: Geologic and edaphic profile in the cliffs; F: Collecting seeds at the study site; G, H: Plants in the cliffs. 
We recognized two main vegetation units in the area, a lauroid forest and a halochasmophytic community. The later develops on the lowest, vertical part of the cliffs, and is dominated by Crithmum maritimum, Silene uniflora subsp. uniflora, Rumex acetosa subsp. biformis, Mathiola incana, Armeria pubigera, Festuca rubra subsp. pruinosa and Angelica pachycarpa. This vegetation type fits under the Crithmo-Armerietalia phytosociological order (FERnANDEZ-Prieto \& HERRERA-Gallastegui, 1992; DíAZ-GonZÁLEZ, 2009). The lauroid community is dominated by several perennifolious tall shrubs or dwarf trees (Laurus nobilis, Ficus carica, Salix atrocinerea), vines (Hedera sp., Lonicera periclymenum) and other species (Osmunda regalis, Rubus sp., Ulex europaeus, Calluna vulgaris, Erica cinerea, Teucrium scorodonia, Pteridium aquilinum, Glandora prostrata). It corresponds to the Calluno vulgaris-Lauretum nobilis phytosociological community (RoDRíGUEZ GUITIÁN \& al., 2007). In our locality, B. oleracea occurs sparsely in the halochasmophytic community and in the lauroid forest, but the highest density was found in the contact line between both communities (Figure 2C).

\section{DISCUSSION}

\section{NEW RECORDS AND DISTRIBUTION AREA}

This new record represents an increase in the species total area of c. $100 \mathrm{~km}$ considering the locality in the Berlengas islands as a recent naturalization (TAULEIGNE GoMes, 2002), the closest population is found in Cudillero, Asturias (Figure 1). Thus, this is the western-most locality of wild native populations of $B$. oleracea. Vegetation type and ecology is, in general terms, in accordance with data from other Cantabrian localities (FernandeZ-Prieto \& HerRera-Gallastegui, 1992; GómEZ-CAMPO \& al., 2005). However, no relation with gulls nesting areas, as reported in the Cantabrian areas, could be established. We consider that, given the efforts done in field prospection, there are no more wild populations of the species in the area although more search will be desirable, especially in some inaccessible areas such as small islands.

\section{CONSERVATION}

Despite its use as a cultivated species, $B$. oleracea occurs in highly sensitive areas as coastal cliffs are, and have been considered a threatened species in different territories. In Asturias, the species is included in the Endangered Flora Catalogue as "Vulnerable" (FERNÁNDEZ PRIETO \& al., 2007) and ranks 82 in the endangered species list of the community according to JiMÉNEZ-ALFARO \& al. (2007). The species is not threatened in Spain or its overall distribution, but should be included in the Galician regional red list. A limited number of reproductive individuals of c. 400 plants were recorded and this is in accordance with other studies that record a low number of plants in each population (i.e. mean of 200 plants in UK, (Mitchell \& Richards, 1979), up to 900 plants in the Cantabrian populations, (GóMEZ-CAMPO \& al., 2005). The population is also limited on its extension, occurring in a restricted section of the coast. Threats to the population include the presence and extension of the exotic invasive species Carpobrotus spp. This perennial plant from South Africa occurs frequently throughout the area, modifying the environmental conditions and excluding native species whenever present (FAGÚNDEZ \& BARRADA, 2007). We consider it a recent invasion, while other impacts such as access improvements are also quite new. Therefore, we conclude there is a probable population decline in recent times, as have been suggested in other areas (Mitchell \& RichaRdS, 1979; Holubec \& al., 2011). Following the IUCN criteria, we propose the following category of threat:

\section{EN B1ab(i,ii,iii)+2ab(i,ii,iii);C2a(i,ii);D1}

Actions for conservation should include germplasm collection (see above), eradication of Carprobrotus in the area, and limiting the construction of new man-made access to the sea 
shore. Further studies on the dynamics and ecophysiology of the population will follow. Also characterization and evaluation of useful traits, including morphological descriptors and agronomical traits, for crop improvement is recommended. This proposal will be submitted to the regional government for its inclusion in the Galician Catalogue of Protected Species.

\section{ACKNOWLEDGEMENTS}

Laura Riesco helped in field survey. Mercedes Herrera provided specific bibliography.

\section{REFERENCES}

Branca, F. \& Cartea, M.E. - 2011 - Brassica - In: Kole, C. (Ed.).Wild Crop Relatives: Genomic and Breeding Resources. Oilseeds. Pp. 17-36. Springer, Berlin Heidelberg.

Carballeira, A., Devesa, C., Retuerto, R., Santillan, E. \& Ucieda, F. - 1983 - Bioclimatología de Galicia. Fund. Pedro Barrié de La Maza, A Coruña.

Cartea, M.E., Lema, M., Francisco, M. \& Velasco, P. 2011 - Basic Information on Vegetable Brassica Crops - In: Sadowski, J. \& Kole, C. (Eds.). Genetics, Genomics and Breeding of Vegetable Brassicas. Genetics, Genomics and Breeding of Crop Plants. Pp. 133. Sci. Publ., Enfield.

Díaz González, T.E. - 2009- Characterization of Natural habitats of Community interest (Natura 2000) existing in the Principality of Asturias. I: Halophilic coastal habitats (dunes, cliffs and salt marshes) - Bol. Ci. Nat. RIDEA 50: 223-280.

Fagúndez, J. \& Barrada, M. —2007- Plantas invasoras de Galicia. Bioloxía, distribución e métodos de control Cons. Medio Amb., Xunta de Galicia, Santiago de Compostela.

Fagúndez, J., Juan, R., Fernández, I., Pastor, J. \& Izco, J. - 2010 - Systematic relevance of seed coat anatomy in the European heathers - Ericeae, Ericaceae) — Plant Syst. Evol. 284(1-2): 65-76.

FAO - 2006 - Guidelines for soil description - Fourth ed. FAO, Rome.

FAO, ISRIC, ISSS — 1998 - World reference base for soil resources. 84 World soil resources reports - FAO, Rome.

Fernandez-Prieto, J.A. \& Herrera-Gallastegui, M. 1992 - Brassica oleracea L.: distribución y ecología en las costas atlánticas ibéricas — Lazaroa 13: 121-128.

Fernández Prieto, J.A., Díaz González, T.E. \& Nava Fernández, H.S. - 2007- La protección de la flora vascular del Principado de Asturias - Naturalia Cantabricae 3: 37-56.

Gómez-Campo, C. -1995- Brassica L. - In: Castroviejo, S. \& al. (Eds.). Flora Iberica, 8. Pp. 362384. R. Jard. Bot., CSIC, Madrid.

Gómez-Campo, C., Aguinagalde, I., Ceresuela, J.L., Lazaro, A., Martínez-Laborde, J.B., Parra-Quijano, M., Simonetti, E., Torres, E. \& Tortosa, M.E. -2005- An exploration of wild Brassica oleracea L. germplasm in northern Spain — Genet. Resour. Crop Ev. 52 (1): 7-13.

Gustafsson, M. \& Lanner-Herrera, C. -1997- Overview of the Brassica oleracaea complex: their distribution and ecological specificities - In: Valdes, B., Heywood, V.H., Raimondo, F.M. \& Zohary, D. (Eds.). Workshops on the Conservation of the Wild Relatives of European Cultivated Plants. Univ. Palermo, Palermo.

Holubec, V., Uzundzhalieva, K., Vörösváry, G., Donnini, D., Bulinska, Z. \& Strajeru, S. - 2011- Brassica oleracea - In: IUCN 2013, IUCN Red List of Threatened Species, ver. 2013.1. www.iucnredlist.org.

Jiménez-Alfaro, B., Bueno, A. \& Fernández Prieto, J.A. 2007- Valoración de plantas de interés para la conservación en Asturias a través de un Índice de Responsabilidad - Natur. Cant. 3: 25-36.

Mei, J., Li, Q., Yang, X., Qian, L., Liu, L., Yin, J., Frauen, M., Li, J. \& Qian, W. —2010 - Genomic relationships between wild and cultivated Brassica oleracea L. with emphasis on the origination of cultivated crops Genet. Resour. Crop Evol. 57 (5): 687-692.

Merino, B. - 1905- Flora descriptiva e ilustrada de Galicia, vol I - Tipografía Galaica, Santiago de Compostela.

Mitchell, N.D. - 1976 — The status of Brassica oleracea subsp. oleracea — wild cabbage - in the British IslesWatsonia 11: 97-103.

Mitchell, N.D. \& Richards, A.J. - 1978 - Variation in Brassica oleracea subsp. oleracea (wild cabbage) detected by picrate test — New Phytol. 81(1): 189-200.

Mitchell, N.D. \& Richards, A.J. — 1979- Biological flora of the British Isles - Brassica oleracea L. - J. Ecol. 67 (3): 1087-1096.

Newton, E., Bullock, J.M. \& Hodgson, D. -2010 Temporal consistency in herbivore responses to glucosinolate polymorphism in populations of wild cabbage Brassica oleracea - Oecologia 164 (3): 689-699.

Ordás, A. \& Cartea, M.E. — 2008 - Cabbage and kale In: Prohens, J. \& Nuez, F. (Eds.). Vegetables I. Asteraceae, Brassicaceae, Chenopodicaceae, and Cucurbitaceae. Handbook of Plant Breeding, vol 1. Pp. 119-149. Springer, New York.

Papadakis, J. - 1966 - Climates of the World and their Agricultural Potentialities - J. Papadakis, Buenos Aires. 
Rigueiro Rodríguez, A. —1977— Trabajo botánico sobre las Islas Cíes — Publ. Min. Agric., Madrid

Rivas-Martínez, S., Díaz, T.E., Fernández-González, F., Izco, J., Loidi, J., Lousã, M. \& Penas, A. -2002Vascular plant communities of Spain and Portugal. Addenda to the Syntaxonomical checklist of 2001 Itinera Geobot. 15(1-2): 5-922.
Snogerup, S., Gustafsson, M., von Bothmer, R. —1990Brassica sect. Brassica, Brassicaceae, I. Taxonomy and variation - Willdenowia 19: 271-365.

Tauleigne Gomes, C. —-2002 - Nouvelles citations pour la flore de 1'archipel des Berlengas (Estremadura, Portugal) — Acta Bot. Malacitana 27: 261-268.

Received: 26 May 2015

Accepted: 23 October 2015 